\title{
Dietary structural types of polygastric herbivores at differ- ent environments and seasons
}

\author{
ALICIA PELLIZA, PRISCILA WILLEMS, AND MARCELA MANACORDA
}

Authors are research technicians at the Instituto Nacional de Tecnología Agropecuaria (INTA), Estación Experimental Agropecuaria Bariloche, CC 277, (8400) San Carlos de Bariloche, Río Negro, Argentina.E-mail: ebariloc@bariloche.inta.gov.ar

\begin{abstract}
A classification of dietary structural types that represents different arrangements of forage classes is proposed. It may be especially useful for interpreting and comparing herbivore diets from different environments. As an example, a data set with the botanical composition of 55 pooled fecal samples determined by microhistological analysis was analyzed. These samples came from 4 species of range herbivores (cattle, sheep, goat, and guanaco -Lama guanicoe-), from 9 different environments of Northern Patagonia (Argentina) during 3 seasons. Based on plant characteristics related with the capacity of the animals to eat and digest each plant and with the occasional or permanent presence of them in the vegetation, the information was grouped into 5 forage classes: woody plants, perennial grasses, annual grasses, grasslikes, and forbs. A principal component analysis of the grouped data was conducted. The graphic representations evidenced the gradual changes in the structure of the data. Later, working over the subspace defined by the 3 first principal component axes, a hierarchical classification was performed that resulted in 9 dietary structural types. These types represented variation that resulted from the interaction of pasture differences, species of herbivore and season. This concept is an abstraction developed from the experience, to extend its utility beyond the particular cases.
\end{abstract}

Key Words: botanical diet composition, conceptualization, forage classes, microhistological analysis, multivariate analysis, similarity of diets.

The diets of livestock and wildlife in the shrub, shrub-grass steppes, and the mountain forests of Patagonia (Argentina) result from the complex interaction between available forage and animal species, their metabolic and reproductive status, the presence of predators and especially the location of water, as pointed out as a generalization by O'Reagain and Swartz (1995). Herbivores select diets from available forage in relation to their nutritional requirements (Hanley 1982).

The authors wish to thank Ing. Agr. H.R. Taddeo for his helpful suggestions, Ing. Agr. G.L. Bonvissuto, and Dr. M.S. Cid for the revision of the manuscript; the anonymous reviewers and the editor of the J.R.M. for the valuable contribution through their critical analysis; and Ms. S. García and Mr. V.C. Rocchi for their help with manuscript preparation and graphic displays. This work was supported by the Instituto Nacional de Tecnología Agropecuaria (INTA), Estación Experimental Bariloche.

Manuscript accepted 12 Sept. 0000.

\section{Resumen}

Se propone la clasificación de tipos estructurales de dietas, que representan diferentes ordenamientos de clases forrajeras previamente definidas. La misma puede ser especialmente útil para interpretar y comparar la dieta de herbívoros en diferentes ambientes. Como ejemplo se analizó un conjunto de datos correspondiente a la composición botánica, determinada mediante el análisis microhistológico, de 55 muestras compuestas de heces. Estas muestras provinieron de 4 herbívoros (bovino, ovino, caprino y guanaco -Lama guanicoe-), en condiciones extensivas de pastoreo en 9 ambientes diferentes del norte de Patagonia, en 3 estaciones. En base a características de las plantas relacionadas con la capacidad de los animales de comerlas y digerirlas y con la presencia ocasional o permanente de las mismas, la información fue agrupada en cinco clases forrajeras: plantas leñosas, gramíneas perennes, gramíneas anuales, hierbas y graminoideas. A partir de los datos agrupados se realizó un análisis de componentes principales. A través de sus representaciones gráficas se evidenciaron los cambios graduales en la estructura de los datos. Trabajando sobre el subespacio definido por los tres primeros ejes factoriales, se hizo una clasificación jerárquica, para formar los grupos que dieron origen a nueve tipos estructurales de dieta. Estos tipos representan variaciones resultantes de la interacción de diferencias entre pasturas, especie de herbívoro y estación. Este concepto es una abstracción desarrollada a partir de la experiencia, para que su utilidad trascienda los casos particulares.

Indices of diversity, diet overlap and/or selectivity have been used to describe and compare the botanical composition of range herbivore diets in Patagonia (e.g., Bonvissuto et al. 1982, 1986, Bonino et al. 1986) and by other authors in many other countries. However, Scarnecchia (1996) pointed out, as did other authors cited in his work, that these indices have little general use in the science of range management.

McInnis et al. (1990) applied hierarchical cluster analysis to the similarity indices to reveal patterns difficult to recognize in the matrix of similarity coefficients. Other multivariate methodologies such as principal component analysis and correspondence analysis have been used to analyze dietary information (Manacorda et al. 1996, Posse et al. 1996, Pelliza et al. 1997).

Conceptual models have been developed to explain foraging behaviors. Senft (1987) stated that generalized models might be useful to predict the response of the animal to changes in the composition of the plant communities or landscape mosaics. 
Hofmann (1989) classified ruminants into 3 feeding types: concentrate selectors, intermediate, and grass-roughage eaters. Provenza and Balph (1990) examined this classification and other models of dietselection in ruminants, which are not mutually exclusive. They found that models based on morphophysiological characteristics and body size provide general predictions about foraging in unfamiliar environments and foraging in environments where the abundance and nutritional quality in dietary items vary temporally and spatially. Referring to mathematical models, Walker (1993) pointed out that the existence of several simulation models competing to explain foraging behavior suggests the difficulty in explaining diet selection by mathematical expressions.

To interpret changes in vegetation in rangelands, Friedel et al. (1988) reduced a large number of species to a small number of "functional groups," based on attributes selected according to their relevance for management. Similarly, defining forage classes according to the characteristics of the herbivores and the vegetation communities could enhance interpreting and comparing data from diets.

The objective of this study was to develop a new method for describing and interpreting diet information based on dietary structural types. This analysis is especially useful when studying diets from different environments. The usefulness of this procedure is demonstrated by analyzing diets of 4 polygastric herbivores grazing in different environments of Northern Patagonia.

\section{Materials and Methods Study area}

The Río Negro Province, Argentina, is included in the vast region known as Patagonia. It has an area of $203.013 \mathrm{~km}^{2}$ and extends $758 \mathrm{~km}$ from the Andes Mountains to the Atlantic Ocean and 485 $\mathrm{km}$ between $37^{\circ}$ and $42^{\circ}$ of south latitude (Fig.1). It has a moderately cold climate in the west and varies to warm-temperate toward the northeast (Soriano 1983). Mean annual precipitation, in part as snow, decreases from more than 2,000 $\mathrm{mm}$ in a forest dominated strip in the west to $150 \mathrm{~mm}$ in the central area, and increases again to $300 \mathrm{~mm}$ on the east of the Province. More than half of the Río Negro Province has a mean annual precipitation lower than $200 \mathrm{~mm}$ (Fig. 1). Strong, constant winds prevail from the west yearlong (Muñoz and Garay 1985, Bustos 1996). Most of Río Negro Province rangelands are in the semiarid environments, with extensive grazing units.
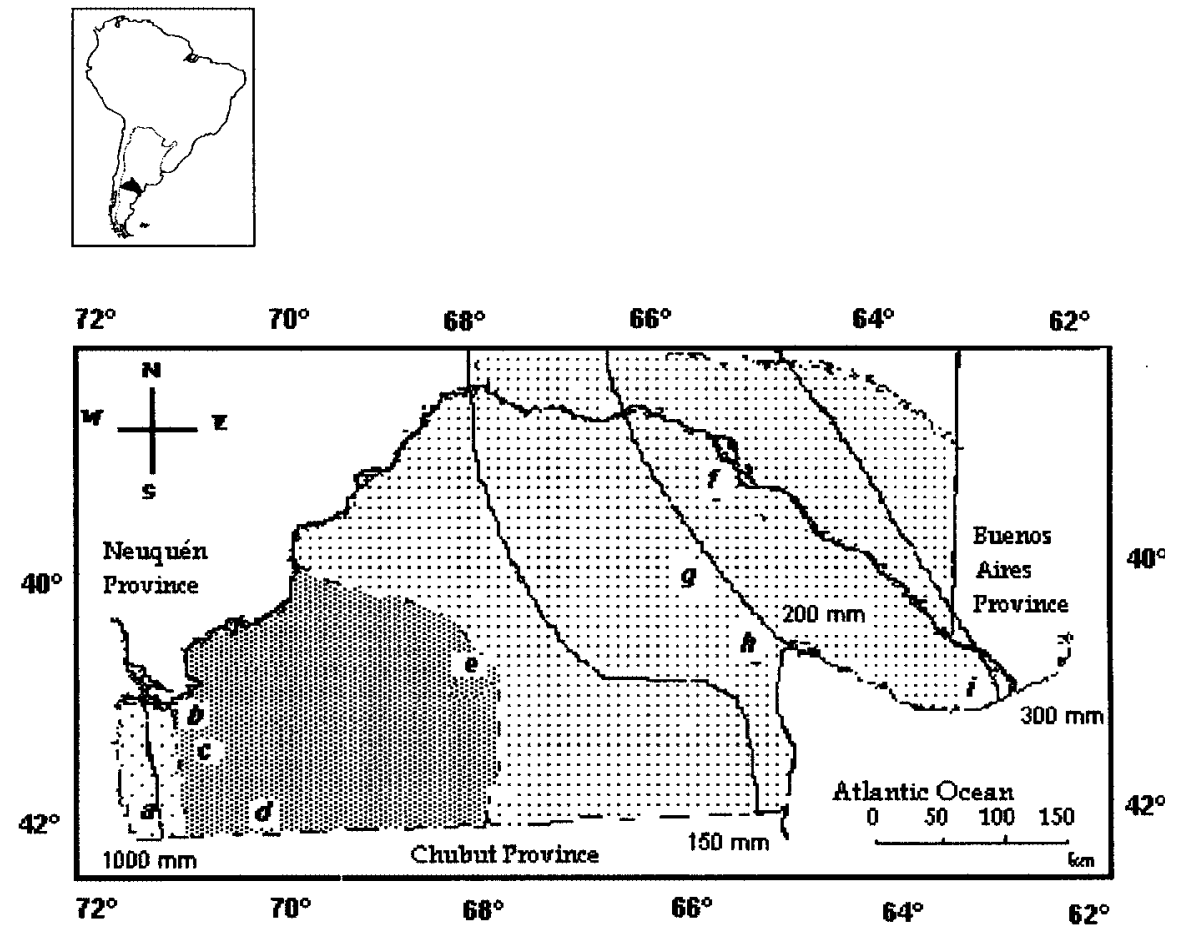

References: Phytogeographical Provinces
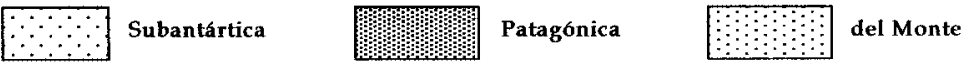

Fig.1. Location of Pastures $a$ to $i$ in the Río Negro Province, Argentina (South America) with the phytogeographical provinces (Cabrera, 1976) and isolines of precipitation. Map adapted from Ragonese \& Piccinini (1969) and Muñoz \& Garay (1985).

Cabrera (1976) described the phytogeographical regions and provinces of Argentina and Soriano (1956) subdivided one of the provinces in districts. The phytogeographical areas for Río Negro province are described in Table 1 and their locations presented in Figure 1. Diets of cattle, sheep, goat, and guanaco (Lama guanicoe) located in 9 pastures distributed across the Rio Negro Province were used in this study (Fig.1).

\section{Analysis of diets}

A minimum of 15 fecal samples from each of 4 herbivore species (cattle, sheep, goat, guanaco) were collected, when present, in each pasture during the summer, winter, and spring of 1991. Following 6 years of drought, the annual rainfall during the study was slightly greater than the mean (Unpublished data, Bustos). The feces were pooled to obtain 55 composite samples, each one of them corresponding to each combination of pasture, season, and animal species, which is referred to hereafter as a diet. Samples were analyzed microhistologically according to Holechek and Vavra (1981), determining percentage of frequency in accordance with Holechek and Gross (1982).
The plant species identified were classified as belonging to 1 of the following 5 "forage classes" based on morphological and anatomical characteristics, related to the capacity of the herbivores to eat and digest them, and their perennial or ephemeral availability:

1. Woody plants (WP): stems and roots with secondary structure, characterized by lignified cellular walls

2. Forbs $(\mathrm{F})$ : without secondary structure and with high digestibility

3. Perennial grasses (PG): without secondary structure with lignified cellular walls

4. Annual grasses (AG): without secondary structure with less lignified cellular walls than $\mathrm{PG}$

5. Grasslike plants (G) (Juncaceae and Cyperaceae families): without secondary structure and digestibility similar to the PG.

Hanley (1982) showed that woody plants (WP) offer easily digestible forage with good nutritive quality in their buds, flowers, and fruits. Similarly, Somlo et al. $(1985,1997)$ reported that in our study area WP had good nutritive quality. Perennial grasses constituted an abundant and permanent forage, while the annual 
Table 1. Characterization of the phytogeographical regions, provinces and districts in the study area.

\begin{tabular}{|c|c|c|c|c|}
\hline Region & Province & District & Description & Pastures \\
\hline AUSTRAL & Subantártica & & $\begin{array}{l}\text { Forests with tree species of austral distribution, mainly of the genus } \\
\text { Nothofagus (Cabrera 1976). Grazing predominates in the forest of } \\
\text { the deciduous "Nire", Nothofagus antarctica, with grasses and } \\
\text { forbs in the understorey. There are meadows with grasslike } \\
\text { plants as: Juncus spp., Carex spp. and Eleocharis spp., grasses as } \\
\text { Poa pratensis and forbs as Trifolium repens (Manacorda et al. 1996). }\end{array}$ & $a$ \\
\hline \multirow{3}{*}{$\begin{array}{l}\text { NEO } \\
\text { TROPICAL }\end{array}$} & \multirow[b]{2}{*}{ Patagónica } & Occidental District & $\begin{array}{l}\text { Characterized by tussock grasses (Stipa spp., Poa ligularis) } \\
\text { and cushion-like shrubs as Mulinum spinosum and Senecio spp. } \\
\text { (Soriano 1956). There are meadows characterized by Juncaceae, } \\
\text { Cyperaceae and perennial grasses, such as Juncus spp., Carex spp. } \\
\text { and Festuca pallescens, respectively (Boelcke 1957). Within those } \\
\text { meadows, there are areas with the halophytic grass Distichlis spp. } \\
\text { (Nicora 1978), towards the east (Marcolin et al. 1978). }\end{array}$ & $b, c, d$ \\
\hline & & ---------- & $\begin{array}{l}\text { Plateaus and mountains of the center of the Río Negro Province with an } \\
\text { altitude superior to } 816 \mathrm{~m} \text {. (Ragonese and Piccinini 1969). The dominant } \\
\text { species are: Chuquiraga avellanedae and Nassauvia glomerulosa among } \\
\text { shrubs and Stipa } \text { spp. among grasses. Prosopis denudans and other shrubs } \\
\text { are sporadically present (Soriano 1956). }\end{array}$ & ------ \\
\hline & del Monte & 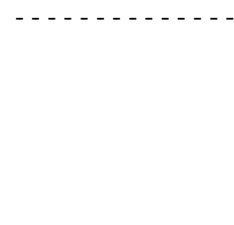 & $\begin{array}{l}\text { Xerophile, sandy and halophile steppes predominate, with short-shrubs, } \\
\text { succulent and ephemeral species. The characteristic community is the } \\
\text { "Jarillal" (pastures } \boldsymbol{h} \text { and } \boldsymbol{i} \text { ), an association of Larrea spp., with } \\
\text { Monttea aphylla, Bouganvillea spinosa and other plants (Cabrera 1976). } \\
\text { In the salinized depressions (pastures } \boldsymbol{f} \text { and } \boldsymbol{g} \text { ) a community characterized } \\
\text { by halophytic shrubs of the genus Atriplex spp. dominates (Morello 1958). }\end{array}$ & $f, g, h, i$ \\
\hline
\end{tabular}

grasses (AG) have occasional presence. Grasslike plants are restricted to meadows.

\section{Statistical analysis}

To obtain dietary structural types, the data were grouped into the 5 forage classes and analyzed. They were arranged in a matrix $A=\left\{a_{i j}\right\}$, for $i=1, \ldots, 55 ; j=1, \ldots, 5$; being the element $\mathrm{a}_{\mathrm{ij}}$ the percentage of the forage class " $\mathrm{j}$ " in the diet "i." Principal component analysis (PCA) was performed on this matrix to represent the data in a space of reduced dimensions with optimal properties (Lebart et al. 1995). The results of PCA allowed evaluating the similarity of diets, expressed through their proximity in the vectorial space. Diets with closer scores (coordinates of diets in the factorial axes) are more similar. These scores are a linear combination of the original dietary composition data that maximizes the variation in these resultant scores with the restriction that the different sets of principal component scores are not correlated to each other. This PCA also describes the correlation structure of the variables.

Next a hierarchical classification was carried out, according to the criterion of minimal variance, working over the subspace defined by the first 3 principal components. The semipartial $\mathrm{R}^{2}$ was the statistic used to evaluate the change produced in the k-th step. This statistic expresses the magnitude of the increment in variability due to the union made in that particular step, relative to the total variance of the data. The objective of this analysis was to create the groups, characterizing them by the biological interpretation of the factorial axes employed. The groups were obtained by cutting the dendrogram with a continuous line, not necessarily straight, according to Benzécri (1992). The dendrogram was cut at a subjective level, which was established to get groups with a biological meaning in order to define the dietary structural types. Data analysis was conducted using SAS (1988).

\section{Definition of dietary structural types}

The dietary structural types represent different arrangements of the 5 forage classes. The terms a) characterized, b) accompanied, and c) associated were used to define the proportion of the diet that the forage classes represented. A forage class characterized a group of diets if it comprised the majority of those diets, whereas a forage class was considered accompanying if it was in a lower proportion. When the majority of the diets of a group had 2 forage classes in similar proportions, they were defined as associated.

\section{Results}

Table 2 shows the plant species or genus identified with values greater than $10 \%$, grouped by forage class, pasture, season and herbivore. Figure 2a shows the first factorial plane of the PCA made on the dietary space (accounting for 47 and 28\% of the total variation by axes 1 and 2 , respectively), and Figure $2 b$ presents the factorial plane of the variable space (i.e., forage class). Woody plants were separated from perennial grasses and grasslikes on the first PCA axis, with their estimated correlation coefficients $r$ being: $r_{\mathrm{WP}, \mathrm{PG}}=$ -0.83 and $r_{W P, G}=-0.67$. Figure 3 shows the dendrogram corresponding to the cluster analysis made with the diets described by the scores given by the first 3 axes of the PCA, and the resulting 9 groups that were identified. The botanical composition of these groups, at forage class level, was used to develop the 9 dietary structural types defined in Table 3.

Cluster analysis grouped $64 \%$ of the diets into structural types I, II, III, IV, and $\mathrm{V}$ based on the proportion of perennial grasses or woody plants in the diet (axis 1, Fig. 2b). This first component accounted for differences between the Monte and the other 2 phytogeographical provinces. The perennial grass-woody plant gradient was also seen in structural types VI, VII, VIII, and IX, which were separated along the second principal component axis based on the occurrence of forbs and annual grasses (axis 2, Fig 2b) and by perennial grasses and grasslikes (axis 3, which was used in the classification). The group defined as the structural type IX is more heteroge- 


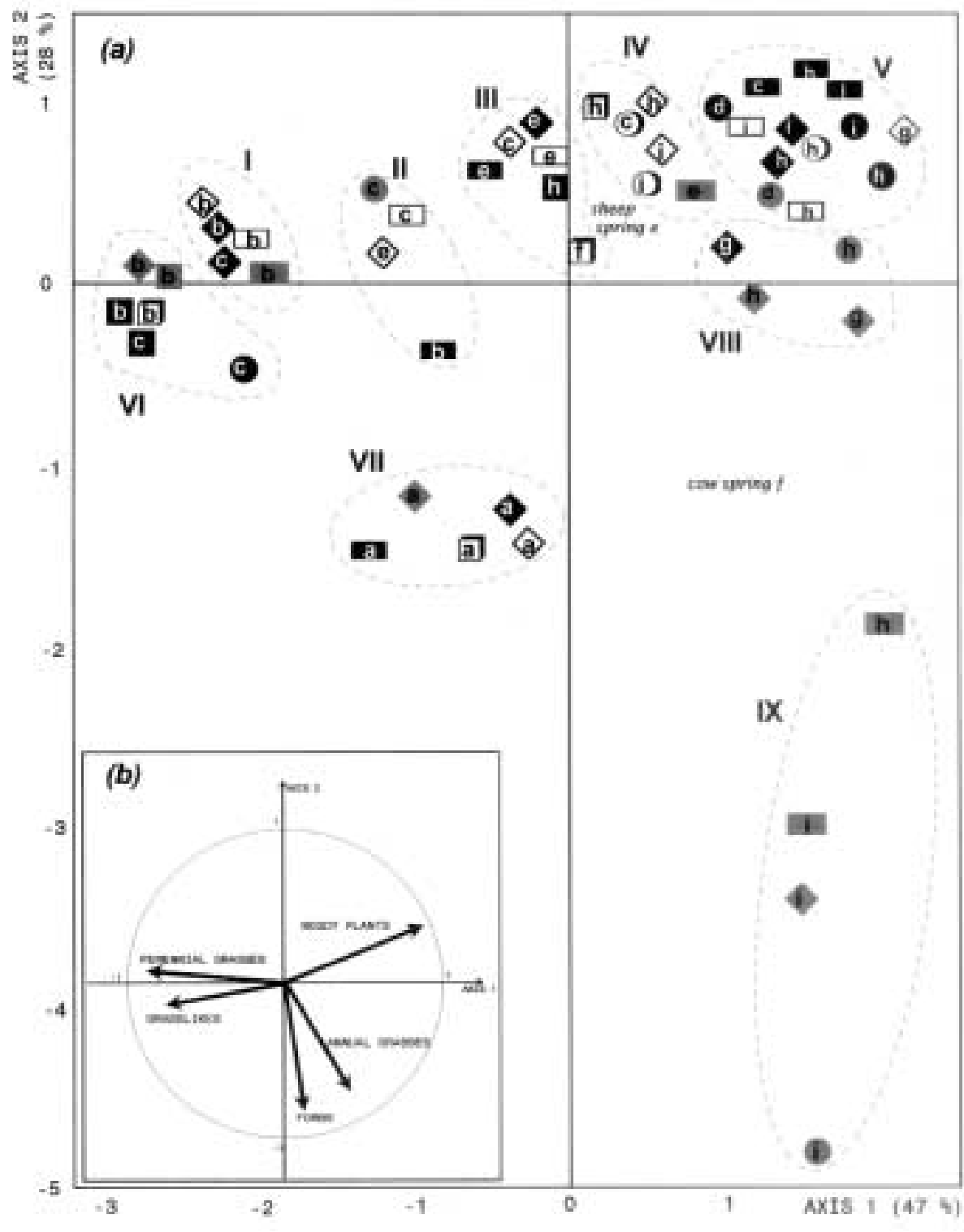

Fig 2. First factorial plane of the Principal Component Analysis of diet composition data, expressed in 5 forage classes, of 4 different herbivores from 9 pastures and 3 seasons. (a) Representation of the dietary space. Labels of the diets: CATTLE: $\square$ summer, $\square$ spring, $\square$ winter; SHEEP: $\downarrow$ summer, $>$ spring, † winter; GOAT: 1 summer, I spring, m winter; GUANACO: $\mathrm{n}$ summer, $\mathrm{n}$ spring, o winter. The letter inside represents the pasture. The percentages of the total inertia explained by each axis are expressed between parenthesis. The diets that belong to each Dietary Structural Type (in roman numbers) are enclosed by a shut dotted line. (b) Representation of the variables (forage classes).

neous than the others, but it was taken as a single cluster because of the availability of the annual grasses, which characterized it, is more variable than the other forage classes. Two of the 55 diets analyzed did not correspond completely to the characterizations given to the structural types IV and VIII, so they were excluded. In the first case, the diet was the only one with a
The location of diets from pastures $\boldsymbol{b}$ and $c$ on the first principal component axis (Fig. 2a) shows that most of the grazing in the Patagónica Province, Occidental District (Table 1), occurs in the meadows Bonvissuto et al. 1996. The diets of the 4 herbivores in pastures $\boldsymbol{b}$ and $\boldsymbol{c}$ contained a high proportion of perennial grasses with different proportions of grasslikes. In the Central District of the Patagónica Province and in the Monte, the steppes become predominant (Table 1), with different combinations of shrubs with perennial and/or annual grasses. Thus, in the dietary structural types of pastures $\boldsymbol{e}, \boldsymbol{f}, \boldsymbol{g}, \boldsymbol{h}, \boldsymbol{i}$, woody plants were especially important, combined with different proportions of the other forage classes, apart from grasslikes. This tendency is more evident in sheep, goat, and guanaco diets than in cattle diets.

The communities of the Phytogeographical Subantárctica Province (Table 1) have a variety of perennial grasses, woody plants, grasslikes, and forbs available. Therefore, in all seasons, the diets of sheep and cattle, corresponding to pasture $\boldsymbol{a}$, were characterized by an association of all the forage classes considered, excluding the annual grasses.

It can also be noted (Fig. 2a) that there are dietary structural types defined almost exclusively by diets corresponding to one pasture: type VII by pasture $\boldsymbol{a}$ and types I and VI by pasture $\boldsymbol{b}$. Those pastures always containing grasslikes have greater forage availability than the pastures of the steppes.

Given the geographical location effect in the graphical diet distribution, the results also show a seasonal effect. It is especially evident in the dietary structural types $\mathrm{V}$, mostly defined by summer diets, and in types VIII and IX, which are defined almost exclusively by spring diets (Fig. 2a.). In both cases, this remark is related with the seasonal foraging availability: in the first case, by woody plants that include fruits, and in the latter, by the presence of annual grasses (Tables 2 and 3).

Other authors (Bonino et al. 1986, McInnis et al. 1990, Manacorda et al. 1996) found a relationship between the results of dietary studies and animal species considered, although subordinated to the influence of the plant community. In this group of samples, 2 known tendencies were evident: a) Cattle tended to have diets characterized by grasslikes and perennial grasses, with minor influence of woody plants and b) the other herbivores, especially goat, tended to have dietary patterns with a strong component of woody plants (Figs. 2a, 2b, and 4). 
Table 2. Plant species contributing $10 \%$ or more to the diets of 4 different herbivores in Northern Patagonia, Argentina. Diets are grouped by herbivore, pasture and season.

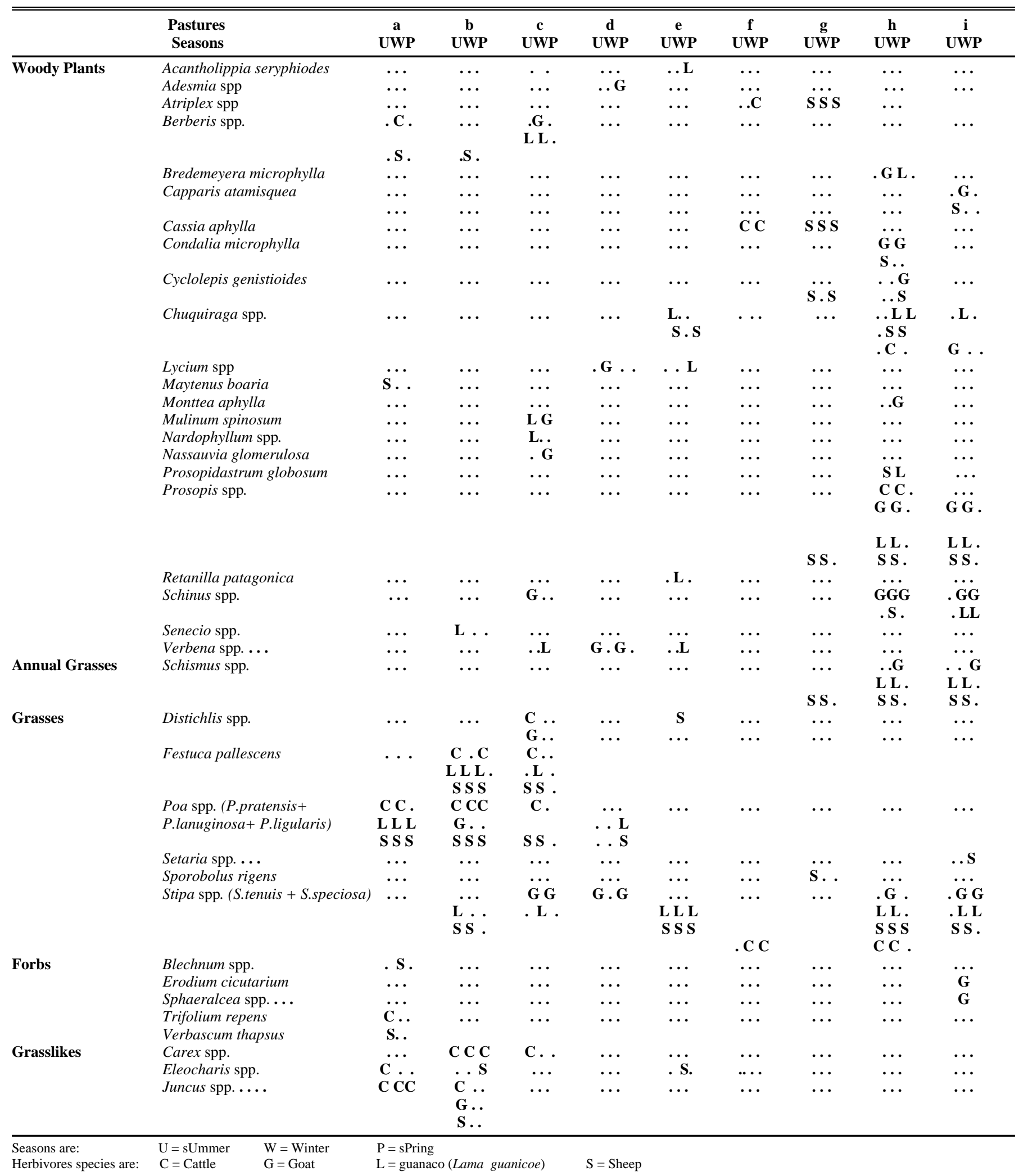




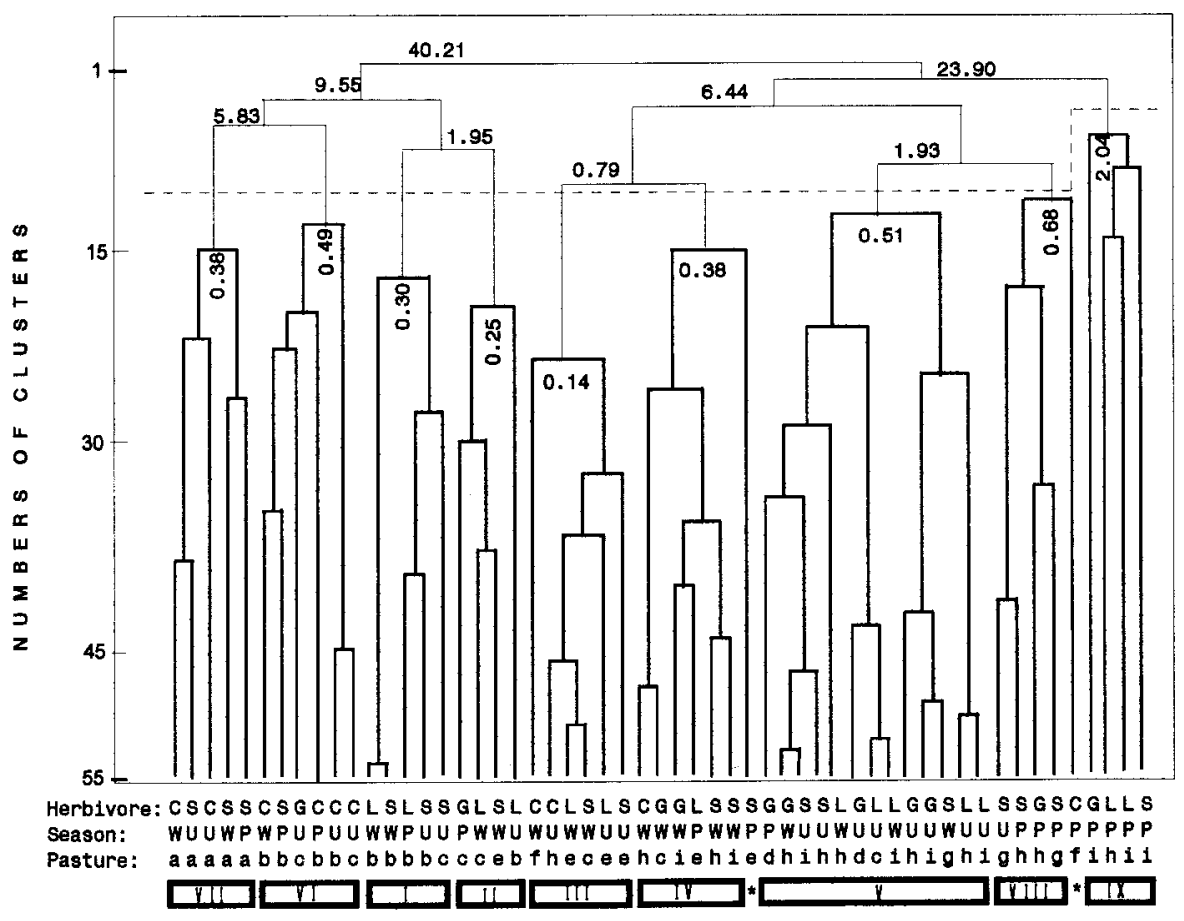

Fig. 3. Dendrogram of the cluster analysis based on the first three factorial axes of the PCA. The numbers are semipartial $R$ square. Bold numbers represent the result from the last union that originate the clusters shown with bold lines. Soft numbers result from the unions above the last ones considered. The dotted line shows where the dendrogram was cut. $\mathbf{C}=$ Cattle, $\mathbf{G}=$ Goat, $\mathbf{L}=$ guanaco $($ Lama guanicoe $), \mathbf{S}=$ Sheep. $\mathbf{P}=$ sPring, $\mathbf{U}=$ sUmmer, $\mathrm{W}=$ Winter. Pastures $=\mathbf{a}$ to $\mathrm{i}$. Dietary structural types $=\mathrm{I}$ to IX. Asterisks correspond to diets that were excluded from those patterns.

\section{Discussion and Conclusions}

Frequently, the lists of genus and/or plant species obtained through the survey on rangelands or through the analysis of range herbivore diets, are not enough to understand the complex animal-plant interaction. To get a more integral interpretation, plants generally are grouped into functional categories that are independent of taxonomic classification. Different functional groupings based on research objectives or characteristics of available forage have been proposed by Bonvissuto et al. (1996), Posse et al. (1996), and Friedel et al. (1988), among other authors. The forage classes proposed here are useful for the interpretation of the diet information from different environments.

This study differs from McInnis et al. (1990) in the objective and in methodological aspects. In this case, the objective is not only the classification of diets, but also the interpretation and the comparison of the foraging response of herbivores in different environments. About the transformation applied to the original dietary composition data prior to the classification of the diets using cluster analysis, McInnis et al. (1990) reduced the matrix of mean seasonal percentage botanical composition of could be seen, sometimes evidencing gradual changes. Instead, the classification methods, as cluster analysis, try to find discontinuities in the data, obtaining groups of similar individuals as a result. In Figure 2a, the groups that are clearly different can be separated from the others that, even when having more similarities within groups than between groups, show a slow and gradual change in the dietary composition. The biological meaning of the identified clusters in this study was based on the biological interpretation of each principal axis.

In an extensive work on most of Patagonia, Pelliza et al. (1997) employed a similar methodology (multiple correspondence analysis and cluster analysis), with the objective of systematizing the results of a dietary survey in the dominant production systems of the principal environments of Patagonia. Starting with dietary information from more than 300 fecal samples representing 10 monogastric and polygastric herbivores, in 3 seasons they defined 20 dietary types or patterns and presented them in cartographic form. The present work proposes to extract directly from the dietary information the conceptualization of dietary structural type. These types, in the sense proposed here, are a generalization that integrates the particular cases, helping in the interpretation of the variation found in the real situations. In Nature only the variation is real and the named "types" are statistical abstractions (Unpublished work, Valverde). The dietary structural types defined here do not differ conceptually from the dietary types or patterns of Pelliza et al. (1997). The different terminology was used to avoid confusions due to the meaning given to these terms in other works (McInnis et al. 1990, Owen-Smith 1993). allowing their distribution to be shown in graphics. Possible structures of the data

Table 3. Dietary structural types defined by cluster analysis of the scores obtained from the first 3 principal component axes of the PCA made on diet composition data expressed in 5 forage classes, of 4 different herbivores from 9 pastures and 3 seasons.

\begin{tabular}{ll}
\hline \hline $\begin{array}{l}\text { Dietary } \\
\text { Structural } \\
\text { Types }\end{array}$ & \multicolumn{1}{c}{ Description } \\
\hline I & Diets characterized by perennial grasses \\
II & Diets characterized by perennial grasses accompanied by woody plants. \\
III & Diets characterized by perennial grasses associated with woody plants. \\
IV & Diets characterized by woody plants accompanied by perennial grasses. \\
V & Diets characterized by woody plants. \\
VI & Diets characterized by grasslikes associated with perennial grasses. \\
VII & Diets characterized by perennial grasses associated with woody plants, accompanied by \\
& grasslikes and forbs. \\
VIII & Diets characterized by woody plants, accompanied by perennial grasses and annual grasses. \\
IX & Diets characterized by annual grasses associated with woody plants, accompanied by \\
& perennial grasses with a variable presence of forbs. \\
\hline
\end{tabular}




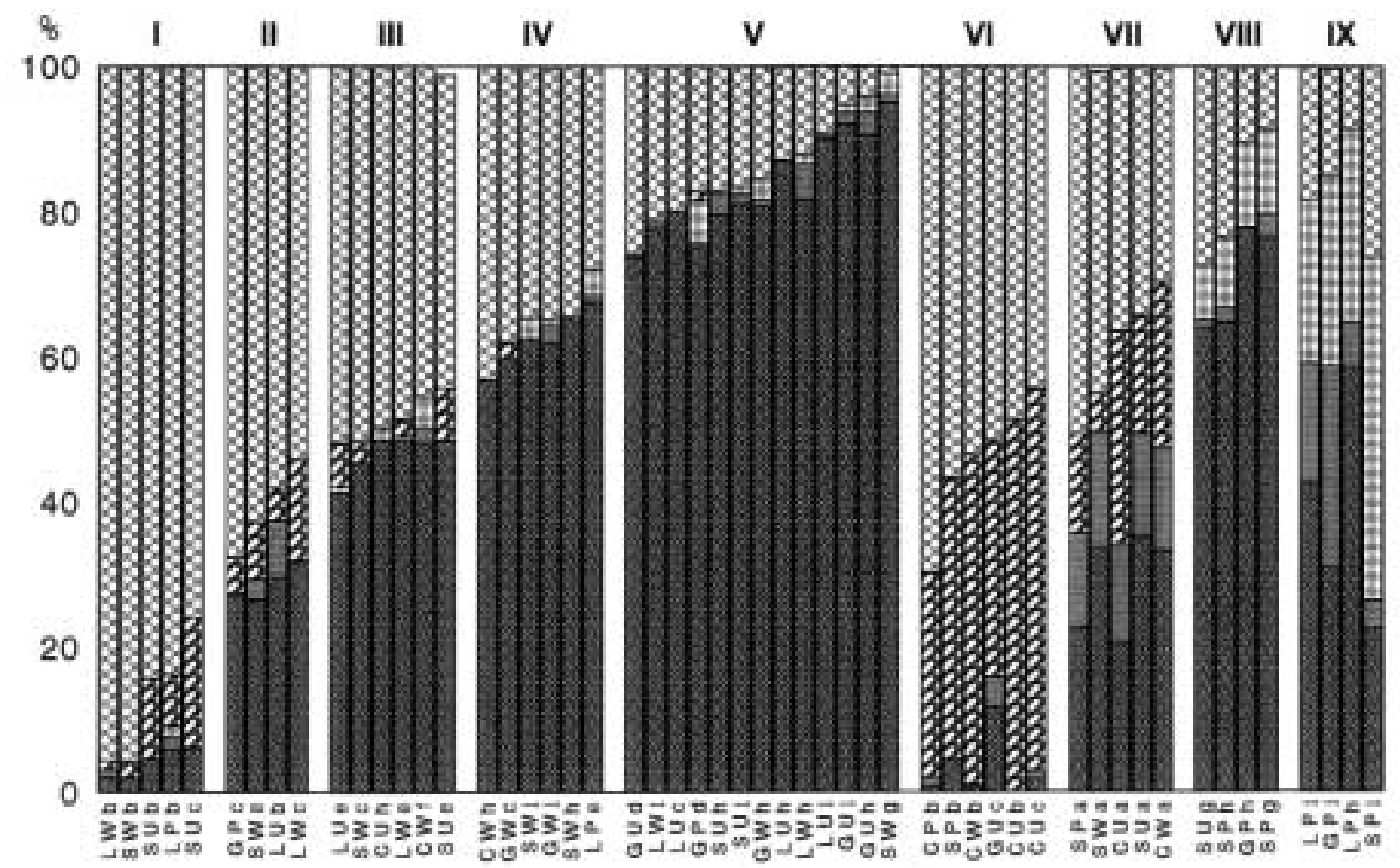

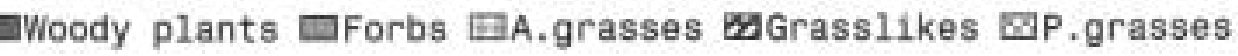

Fig. 4. Forage classes composition of diets grouped on the defined Dietary Structural Types (I to IX). C = Cattle, G = Goat, L = guanaco (Lama guanicoe), $\mathrm{S}=$ Sheep. $\mathrm{P}=$ sPring, $\mathrm{U}=$ sUmmer, $\mathrm{W}=$ Winter. Pastures $=\mathbf{a}$ to $\mathrm{i}$.

With respect to the interpretation of plant-herbivore interaction, Senft (1987) suggested that there might be basic patterns of this interaction that are independent of vegetation type and perhaps of plant species, and that those patterns could differ with level of ecological organization. In this work, it was found that some of the dietary structural types were not independent of the structural and specific characteristics of the vegetation of each region, although they were conditioned to animal characteristics, as discussed by Hanley (1982). Thus, this approach helps in setting up the interaction between the herbivore morphophysiology and the vegetation type. There are cases, in which the same herbivore has similar diets in different environments, whereas in other cases, different herbivores at different environments have similar diets.

The concept of structural types defined in this study fulfills the characteristics cited by Scarnecchia (1996) for any conceptualization: it is an abstraction developed from the experience attempting to generalize the information so that its use transcends the particular cases. The types based on the contribution of forage classes in the diets may be integrated in future studies, to develop more complex conceptual models of dietary selection.

\section{Literature Cited}

Benzécri, J.P. 1992. Correspondence Analysis Handbook. Ed. Marcel Dekker, Inc., N.Y.

Boelcke, O. 1957. Comunidades herbáceas del norte de Patagonia. Rev. Inv. Agric. XI(1).

Bonino, N., G. Bonvissuto, A. Pelliza Sbriller, and R. Somlo. 1986. Hábitos alimentarios de los herbívoros en la zona central del área ecológica Sierras y Mesetas Occidentales de Patagonia. Rev. Arg. Prod. Anim. 6 (5-6):275-287.

Bonvissuto, G., E. Moricz, O. Astibia, and J. De Anchorena. 1982. Resultados preliminares sobre los hábitos dietarios de ovinos en un pastizal semidesértico de Patagonia. IDIA, INTA, Buenos Aires, Suplemento 36:243-253

Bonvissuto, G., R. Somlo, A. Pelliza Sbriller, and E. Moricz. 1996. Dieta estacional de ovinos restrictos a un mallín en Sierras y Mesetas Occidentales-Patagonia. Rev. Arg. de Prod. Anim. 16(1):35-44.

Bustos, C. 1996. Climodiagramas de localidades seleccionadas de la Provincia de Río Negro. Comunicación Técnica $\mathrm{N}^{\circ} 16-$ Agrometeorología. INTA EEA Bariloche.
Cabrera, A. 1976. Regiones Fitogeográficas Argentinas. Enciclopedia Argentina de Agricultura y Jardinería. Segunda Ed. Tomo II. Ed. Acme S.A.C.I., Buenos Aires: 81 pp.

Friedel, M.H., G.N. Bastin, and G.F. Griffing. 1988. Range assessment and monitoring in arid lands: the derivation of functional groups to simplify vegetation data. $\mathrm{J}$. Environ. Manage., 27:85-97.

Hanley, T.A. 1982. The nutritional basis for food selection by ungulates. J. Range Manage. 35(2):146-151.

Hofmann, R.R. 1989. Evolutionary steps of ecophysiologial adaptation and diversification of ruminants: a comparative view of their digestive system. Oecologia, 78:443-457.

Holechek, J. and B. Gross. 1982. Evaluation of different calculation procedures for microhistological analysis. J. Range Manage. 35 (6):721-723.

Holechek, J.L. and M. Vavra. 1981. The effect of slide and frequency observation numbers on the precision of microhistological analysis. J. Range Manage. 34 (4):337-338.

Lebart, L., A. Morineau, and M. Piron. 1995. Statistique exploratoire multidimensionnelle. Ed.Dunod, Paris.

Manacorda, M., R. Somlo, A. Pelliza Sbriller, and P. Willems. 1996. Dieta de ovinos y bovinos en la región de los bosques de ñire (Nothofagus antarctica) de Río Negro y Neuquén. Rev. Inv. Agr., INTA, Buenos Aires, 26(1):137-146. 
Marcolin, A., G. Durañona, R. Ortiz, E. Sourrouille, M. Latour, and G. Larrama. 1978. Caracterización de mallines en un área del Sudoeste de la Provincia de Río Negro. Comunicación Técnica $\mathrm{N}^{\circ} 13$, Pastizales Naturales. INTA EEA Bariloche.

McInnis, M.L., L.L. Larson, and M. Vavra. 1990. Classifying herbivore diets using hierarchical cluster analysis. J. Range Manage. 43(3):271-274.

Morello, J. 1958. La Provincia Fitogeográfica del Monte. Opera Lilloana II, Instituto Miguel Lillo, Tucumán.

Muñoz, E. and A. Garay. 1985. Caracterización climática de la Provincia de Río Negro. Comunicación Técnica $N^{\circ} 14$ Rec Naturales, Agrometeorología. INTA EEA Bariloche.

Nicora, E. 1978. Flora Patagónica. Parte III. Gramineae, Colección Científica del INTA Tomo VIII. Ed. Correa, M. INTA, Buenos Aires.

O'Reagain, P.J. and J. Schwartz. 1995. Dietary selection and foraging strategies of animals on rangeland. Coping with spatial and tempora variability, p. 407-423. In: M. Journet, E. Grenet, M-H. Farce, M. Theriez, and C. Demarquilly (eds.). Proc. IVth Int. Symp. Nutr. of Herbivores, INRA Editions, Paris.
Owen-Smith, N. 1993. Evaluating optimal diet models for an African browsing ruminant, the kudu: how constraining are the assumed constraints?. Evolutionary Ecol., 7:499-524.

Pelliza, A., P. Willems, V. Nakamatsu, A. Manero et al. 1997. Atlas dietario de herbívoros patagónicos. INTA-GTZ-FAO, Bariloche. ISBN 950-9853-88-7. Ed.: R. Somlo.

Posse, G., J. Anchorena, and M. Collantes. 1996. Seasonal diets of sheep in the steppe region of Tierra del Fuego, Argentina. J. Range Manage. 49(1):24-30.

Provenza, F. and D. F. Balph. 1990. Applicability of five diet-selection models to various foraging challenges ruminants encounter, p. 423-459. In: R. N. Hughes (ed.), NATO ASI Series Vol G 20, SpringerVerlag, Berlin Heidelberg.

Ragonese, A. and B. Piccinini. 1969. Límite entre el Monte y el Semidesierto Patagónico en las Provincias de Río Negro y Neuquén. Boletín Soc. Arg. Bot. 11(4): 299-302.

SAS. 1988. SAS/STAT User's guide.Release 6.03 Ed. Sas Inst.Inc.Cary, N.C.

Scarnecchia, D.L. 1996. Viewpoint: Concept design in range management science. J. Range Manage. 49(5):421-424.
Senft, R.L. 1987. Domestic herbivore foraging tactics and landscape pattern. Symposium on Plant-Herbivore Interactions, USDA-Forest Serv. Intermoun. Res. Station. Gen. Tech Rept, INT - 222:137-140.

Somlo, R., G. Durañona, and R. Ortiz. 1985. Valor nutritivo de especies forrajeras patagónicas. Rev. Arg. Prod. Anim. 5(9-10): 589-605.

Somlo, R., L. Cohen, H. Giorgetti, O. Montenegro, and G. Rodriguez. 1997. Tablas de valor nutritivo de especies forrajeras patagónicas. 2 Monte Pampeano. Comunicación Técnica $\mathrm{N}^{\circ} 65$ - Recursos Naturales-Pastizales Naturales. INTA EEA Bariloche.

Soriano, A. 1956. Los distritos florísticos de la Provincia Patagónica. Rev. Inv. Agr., Tomo X, 4:323-342.

Soriano, A. 1983. Deserts and semi-deserts of Patagonia, p.423-460. In: Temperate Deserts and Semi-deserts, Ed. N.E. West. Elsevier Scientific Publishing Co, Amsterdam.

Walker, J.W. 1993. Nutritional models for grazing animals. BÚVÍSINDI, ICEL. AGR. SCI. 7: 45-57. 